\title{
Mycoplasma gallisepticum in free-range chicken from Northern Tocantins State, Brazil
}

\author{
Caroline Peters Pigatto De Nardi ${ }^{1 \star}$, Aléxia Lohanna Monteiro Lima ${ }^{2}$ and Francisco Baptista ${ }^{2}$ \\ ${ }^{1}$ Instituto Federal de Educação, Ciência e Tecnologia de São Paulo (IFSP), Campus Matão, Brazil. \\ ${ }^{2}$ Universidade Federal do Tocantins (UFT), Faculdade de Medicina Veterinária e Zootecnia, Brazil.
}

Accepted 21 October, 2013

\begin{abstract}
Mycoplasma gallisepticum is a major problem of the poultry industry worldwide. This infectious disease, which affects animals worldwide, is caused by bacteria. The aim of this study was to determine the prevalence of $M$. gallisepticum in free-range chickens raised in Araguaína, Tocantins, using rapid plate agglutination test (SAR). Blood samples of 175 free-range chickens from the city of Araguaína, Tocantins, Brazil, were evaluated through serological tests. Of the $\mathbf{1 7 5}$ blood samples from adult birds (Gallus gallus domesticus), 74 (42.29\%) - [34.87 to 49.97\%] had positive serology for M. gallisepticum. Positive results were significant and show the need for preventive measures in small farms in the region studied.
\end{abstract}

Key words: Poultry, mycoplasmosis, biosafety.

\section{INTRODUCTION}

The avian mycoplasmosis was first known as enzootic pneumonia. It is regarded as one of the serious health problems of the poultry production chain (Yoder, 1991). This infectious disease, which affects animals worldwide, is caused by bacteria within the class Mollicutes (Latin mollis $=$ soft, cutis $=$ skin) distinguished by the absence of a cell wall. Thus, these agents may be present in many forms while spherical is the most frequent (Razin et al., 1998). The main species responsible for mycoplasmosis is Mycoplasma gallissepticum (MS) (Yoder, 1991; Nascimento, 2000).

The presence of $M$. gallisepticum results in severe direct and indirect losses to the poultry industry (Buim et al., 2009). The losses include decreased hatchability and egg production, poor quality chicks, reduced growth rate, in addition to increasing costs with disease eradication procedures, monitoring and control programs (Yilmaz et al., 2011).
The absence of a cell wall makes them naturally resistant to antibiotics, such as penicillin (Buim, 2007). However, since these micro-organisms do not survive outside the host, their survival is usually restricted to a few hours or days, under the usual circumstances of farms (Nascimento, 2001).

According to Mettifogo and Ferreira (2007), the most important sources of infection are either the sick birds or the ones carrying the pathogen. The mycoplasma can be eliminated through the eggs, or the agent can be present in the semen of roosters or the oviduct of hens. Transmission can occur through direct contact with infected birds and indirect contact via contaminated fomites, such as feces and contaminated feathers present in the water and food; and airborne transmission which involves aerosols and droplets. During winter, the respiratory disease is more frequent and more severe in young birds while in the adult bird population is directly related to decreased 
Table 1. Frequency of free-range chicken (Gallus gallus domesticus) seropositive for Mycoplasmosis in Araguaína, TO, Brazil, 2012.

\begin{tabular}{lccc}
\hline Farm & Number of birds & Positive & Percentage (\%) \\
\hline 1 (North region) & 95 & 39 & 41.05 \\
2 (North region) & 32 & 23 & 71.87 \\
3 (South region) & 8 & 0 & 0.00 \\
4 (Center) & 40 & 12 & 30.00 \\
Total & 175 & 74 & 42.29 \\
\hline
\end{tabular}

egg laying. Yoder (1991) reports that together with Mycoplasma synoviae (MG), M. gallisepticum (MS) is one of the most widespread agents in poultry.

According to Ito et al. (2002), the implementation of biosecurity is the main preventive measure that can be adopted to prevent the introduction of $M$. gallisepticum in poultry production. Based on this information, the aim of this study was to determine the prevalence of $M$. gallisepticum in free-range chickens raised in Araguaína, Tocantins, using rapid plate agglutination test (SAR).

\section{MATERIALS AND METHODS}

The blood samples were collected from four poultry farms of Araguaína, of which three were commercial and one small noncommercial farm where the chickens were raised for own consumption. Two are located in the northern region of the city; the small non-commercial farm, in the south; and, the last farm, in the urban area (center) of the city.

Blood samples of 175 birds were randomly collected in four small free-range chicken farms in Araguaína, Tocantins. Blood samples were drawn by humeral venipuncture, identified, placed under refrigeration and immediately sent for serology to the Laboratory of Hygiene and Public Health of the Escola de Medicina Veterinária e Zootecnia, Universidade Federal do Tocantins (UFT).

The blood samples collected from the chicken at the small farms were chilled and transported carefully in order to avoid hemolysis. The centrifugation to obtain the serum was performed in the laboratory of Hygiene and Public Health of the UFT. According to the manufacturer instructions, serology was performed at room temperature between 20 and $25^{\circ} \mathrm{C}$ and the samples were not frozen, since freezing favors nonspecific reactions. The positive reactions, which are characterized by the presence of lumps, were visible within a span of two minutes.

The SAR antigen used was the Myco-Galli Test ${ }^{\circledR}$, which consists of the inactivated suspension of $M$. gallisepticum strain S-6. Firstly, the antigen, the serum to be tested and the positive and negative serum controls were removed from the refrigerator and kept at room temperature for $30 \mathrm{~min}$. Subsequently, the serum sample to be tested was inactivated in a water bath at $56^{\circ} \mathrm{C}$ for $30 \mathrm{~min}$. The test was performed according to the manufacturer's instructions. Confidence intervals of $95 \%$ were determined for the frequencies of seropositivity for Mycoplasma gallisepticum.

\section{RESULTS AND DISCUSSION}

Of the 175 blood samples from adult birds (Gallus gallus domesticus) 74 (42.29\%) had positive serology for $M$. gallisepticum (Table 1). Table 1 also shows the results with respect to the four chicken farms studied.

Knowing the frequency of major infectious diseases in birds is critical to establish a poultry health program. The serological monitoring of large and smaller, more informal poultry farms is fundamental to the establishment of preventive measures (Buchala et al., 2006).

Determining the infection sources by detecting the presence of antibodies is a rapid and practical epidemiological tool. This information shows the contact of birds with the infectious agent, thus demonstrating the presence and circulation of the pathogen in poultry populations (Wray and Davies, 1994). Serological surveys are generally used to support mycoplasmosis control programs (Sato, 1996).

Birds infected with Mycoplasma sp can have their production indices severely affected causing significant losses. Respiratory diseases may condemn carcasses in the slaughtering process and reduce egg production by up to $10 \%$ while increasing mortality due to decreasing immunity (Cardoso et al., 2006). It is also important to know the number of birds positive for $M G$ in the region because seropositivity is related to aerosaculitis that causes weight loss in broilers (Machado et al., 2012). This fact undermines the local economy, in addition to the health issues.

Farm 1 was more organized and had better health management because the aim was to sell the birds in the popular town market. The shaded, covered area was clean and equipped with adequate feeders and drinkers. The feed and the pickets were uniform since the chicks, young chickens, and birds of approximately four months (batch from which blood samples were obtained) were all separated. However, other species were also raised on the property, such as ducks, geese, turkeys and helmeted guinea fowl hens. In this property, $41 \%$ of samples were positive. The high number of seropositive samples may be due to the number and diversity of animals raised in the same location. Furthermore, the grouping and origin of the animals may also have influenced this result. The second farm, located in the northern part of the city also showed high number of positive samples (72\%). The non-commercial farm, situated 
in the southern region of the city, where the birds are only for domestic consumption eight blood samples were drawn. In this third farm, there was no sample positive for MG, which can be explained by the small number of birds surveyed. On the other hand, farm number 4 located in the downtown area had $30 \%$ positivity and a large total number of birds, which may have facilitated the spread of the disease.

The city Araguaína is located in northern Tocantins where control measures to ensure the health of birds are minimal. It is common to find backyard raised chicken near chicken farms, as well as birds of different age and growing stages mixed altogether. These factors contribute to the spread of the pathogen. The implementation of biosecurity measures is paramount in these cases as highlighted by Nascimento et al. (2000).

The high seropositivity for mycoplasmosis in all birds studied, points to the need for preventive measures in small commercial chicken farms.

\section{REFERENCES}

Buchala FG, Ishizuka MM, Mathias LA, Berchieri Júnior A, Castro AGM, Cardoso ALSP, Tessar ENC, Kanashiro AMI (2006). Detecção de resposta sorológica contra mycoplasma em aves de criatórios de "fundo de quintal" próximos a explorações comerciais do estado de São Paulo. Arq. Inst. Biol. 73:143-148.

Buim MR (2007). Micoplasmose aviária. Arq. Inst. Biol. 73:23-26.

Buim MR, Mettifogo E, Timenetsky J, Kleven S, Ferreira AJP (2009). Epidemiological survey on Mycoplasma gallisepticum and Mycoplasma synoviae by multiplex PCR in comercial poultry. Pesq. Vet. Bras. 27:552-556.

Cardoso ALSP, Tessari ENC, Castro AGM, Kanashiro AMI, Stoppa GFZ (2006). Prova de soroaglutinação rápida em galinhas reprodutoras com monitoria sorológica de micoplasmoses. Arq. Inst. Biol. 70:31.
Ito NMK, Miyaji Cl, Lima EA, Okabayashi S (2002). Micoplasmoses em aves. In: Curso básico de sanidade avícola Fort Dodge, 2002, Jaguariúna-SP. Anais... Curso básico de sanidade avícola Fort Dodge, 9:27-53.

Machado L, Nascimento ER, Pereira VLA, Almeida DA, Silva RCF, Santos LMM (2012). Mycoplasma gallisepticum como fator de risco no peso de lotes de frangos de corte com condenação por aerossaculite na Inspeção Sanitária Federal. Pesq. Vet. Bras. 32:745-648.

Mettifogo E, Ferreira AJP (2007). Micoplasmose aviária. In Filho RLA. Saúde Aviária e Doenças. São Paulo: Roca, pp. 147-151.

Nascimento ER (2000). Micoplasmoses aviárias. In Berchieri Junior A, Macari M, Doença das aves. Campinas: Facta, pp. 217-224.

Nascimento ER (2001). Mycoplasma Synoviae em avicultura implicações econômicas: conviver ou erradicar? In Conferência apinco de ciências e tecnologia avícolas, 2001, Campinas- SP. Anais. Conferência apinco de ciências e tecnologia avícolas 1:31-44.

Razin S, Yoguev D, Naot Y (1998). Molecular Biology and Pathogenicity of Mycoplasmas. Microbiol. Mol. Biol. Rev. 62:1094-1156.

Sato S (1996). Avian mycoplasmosis in Asia. Rev. Scient. Tech. Off. Int. Epiz. 15:1555-1567.

Wray C, Davies RH (1994). Guidelines on detection and monitoring of salmonella infected poultry flocks with particular reference to Salmonella enteritidis. In Report of a WHO consultation on Strategies for Detection and Monitoring of Salmonella infected Poutry Flocks, Austria: WHO - Vet. Public Health Unit, pp. 29-34.

Yilmaz F, Timurkaan N, Kiliç A, Kalender H, Kilinç Ü (2011). Detection of Mycoplasma synoviae and Mycoplasma gallisepticum in chickens by immunohistochemical, PCR and culture methods. Rev. Med. Vet. 162:79-86.

Yoder Jr WH (1991). Mycoplasma gallisepticum infection. In Calneck BW, Barnes HJ, Beard C W, Reid WM, Yoder Jr HW. Diseases of poultry. (9 ed) Ames: lowa State University Press, pp. 198-212. 